\title{
Going on Without Hope-Lu Xun's Perception and Struggle to Nihility in Wild Grass
}

\author{
Yuxuan Liu ${ }^{1}$ \\ ${ }^{1}$ International Business School, Beijing Foreign Studies University, Beijing 100089, China
*Corresponding author. Email:liuyuxuan20001015@qq.com
}

\begin{abstract}
Wild Grass was born in the period of political turmoil and Lu Xun's family misfortune. The recurring word "nihility" in the book makes people speculate about its deep meaning. In fact, through the "nihility", mental state of Lu Xun can also be glimpsed. Based on the background of the birth of Wild Grass, this paper makes a deep analysis through the text, Lu Xun's revolutionary ideals and practical experience to discover his active pursuit of the meaning of life. Even though he perceived nihility, he still put the national spiritual state and the revolutionary ideal above himself. Even though he had given up the pursuit of hope, he had never stopped moving towards the future that no one knew whether it would be dark or bright. It can be concluded that going on without hope could be Lu Xun's most obstinate way of struggling to nihility.
\end{abstract}

Keywords: Lu Xun, Wild Grass, nihility, life.

\section{INTRODUCTION}

"Nihility" is an important concept in Wild Grass. However, most of the papers lack in-depth exploration of the inner meaning of nihility. Thorough analysis is often found only in long and professional books. Therefore, the author carefully analyzes the meaning of nihility so that readers can quickly understand Lu Xun's mental state at that time through this paper.

Published in 1927, Wild Grass is a collection of 23 prose poems written by $\mathrm{Lu}$ Xun from 1924 to 1926 . To grasp his mental state during creation, an understanding of the historical background is essential. During the creation of Wild Grass, warlords fight and the March 18th massacre caused lots of chaos. In addition, the dissolution of the new youth team and the break with his younger brother Zhou Zuoren took an even greater spiritual toll on Lu Xun. Lu Xun repeatedly mentioned the concept of "nihility" (including synonyms of "emptiness"'"nothingness", etc) in his prose poetry anthology Wild Grass. After perceiving "nihility", he further explained his attitude towards hope, life and death. In order to understand $\mathrm{Lu}$ Xun's view of hope, life and death from the perspective of "nihility" as well as the context of Wild Grass should be analyzed in depth and the "nihility" should be further explained. Through the analysis of every "nihility" mentioned in Wild Grass, this research deeply analyzes $\mathrm{Lu}$ Xun's perception of "nihility", and discusses Lu Xun's thinking about life. Through this research, readers will have a more specific and detailed understanding of "nihility" in Wild Grass, so as to understand Lu Xun's then mental state and thoughts on revolution.

\section{OVERVIEW OF WILD GRASS}

\subsection{Interpretation of Wild Grass's Preface in Chinese Version}

The first sentence of the preface is "When I open my mouth, I feel empty" [4]. This is the first expression of nihility in the book. Based on Lu Xun's explanation of this sentence in his essay How to Write, readers can know that the emptiness here is directly caused by trying to say something, and the root cause is Lu Xun's struggle in the face of complex emotions such as sadness and distress. When Lu Xun was silent, all his emotions were real; but when he tried to express his feelings, he felt empty because of the complexity of his experience and emotions. The emptiness here can be understood as the unspeakable bewilderment, or it can be deeper: after experiencing many times of disappointment and even despair, knowing that all the sufferings are painful, after careful consideration, Lu Xun feel that even hope is no longer as attractive as before. 
"I have great joy in this death, because by it I know it has lived" [4]. Lu Xun reveals his attitude through the description of weeds: the meaning of life lies not in the result, but in the process. At the same time, with his attitude, several of his images have multiple meanings. Wild Grass is nurtured by the land, but in turn, it ravages the land and is harmful to other plants. Therefore, wild grass here could be the group of people who share the same dream as Lu Xun. They were nurtured by traditional society, but wanted to wake up and create a new world. However, there were too many people who did not want to wake up. Faced with such a situation, Lu Xun wanted to laugh and sing, but he knew it was not the right time. But even if conditions permitted, he could not laugh or sing, which reflected Lu Xun's contradictory spiritual attitude. He did not want to be depressed, but circumstances made it difficult for him to be truly openminded [7].

\subsection{Interpretation of Wild Grass's Preface in English Version}

In the English preface, Lu Xun explained some specific reasons for his creation. Except for responding to the political events of the day, there was an abhorrence at the enormity of the bystanders in society, or a wonder at the depression of the young. For specific events, Lu Xun never changed his bitter satire and strong criticism as a fighter. But that did not mean that he was a revolutionary who always took drastic measures. On the contrary, during the period of creating Wild Grass, Lu Xun even took revenge on the visitors by fighting against nihility, instead of taking sharp knives and spilling their blood. Under such a violent situation, Lu Xun eliminated the enemy's life by boring it [5].

\section{CONCRETE MEANING "NIHILITY" IN WILD GRASS}

\subsection{Meaning of the Word "nihility"}

The word "nihility" has different interpretations in the eastern and western cultures. This paper focuses on the discussion of the word itself and related literary works, rather than the discussion in the philosophical field. Therefore, the author will mainly refer to the more popular explanation, and choose the following words in line with the work to explain the meaning: pure heart, no love and hate; nonsense; nothing at all; blindly denying or rejecting everything, etc. In the following analysis of nihility in Wild Grass, the above explanations will be referred to.

\subsection{Contextual Meaning of "nihility" in Wild Grass}

This paper will first focus on the articles with such words as "nihility", "nothingness" and "emptiness" in Wild Grass, and analyze their contextual meanings.

In Farewell to Shadows, Lu Xun mentions that he had better wander on no land [4]. The shadow is between the dark and the dawn. Combined with the background of the times, the darkness symbolizes the old society and the dawn symbolizes the new society that Lu Xun imagined in his mind. It can be inferred that Lu Xun was willing to be a shadow. The shadow seems to want to stop following the real body, but in fact it is the projection of Lu Xun's inner thoughts when he struggles with reality. The shadow is willing to sink in the darkness, but it also says that what it could give is darkness and emptiness. Setting aside the context, darkness and emptiness are obviously different in meaning, but here Lu Xun regards them as a parallel relationship and even deals with each other in an integrated way. Therefore, the emptiness here is negative, namely "dark", rather than neutral. The attitude of the shadow is to stay between the light and the dark, paving the way for future generations, alone to bear the last darkness before the dawn. What will the shadow have when future generations see the light? As it says, darkness and nothingness. In reality, it represents the price that must be paid for the success of the revolution.

At the end of Begging Man, Lu Xun mentions that he will beg with nothing and silence and he will at least get nihility. Before that, he portrayed another beggar begging for money and food. Different from the beggar, what $\mathrm{Lu}$ Xun really needed was the development of the Times, and his spiritual pursuit. Therefore, "nothing" and "silence" here can be understood as synonyms, indicating that $\mathrm{Lu}$ Xun had ideals but was not willing to pay practical action, for the reality had let him down again and again. Here "nihility" can be understood as "nothingness" on the objective level. Lu Xun's ideal had not been realized, the society was not getting better day by day, and the cause of the past is now facing failure. In the future, there may be hope, but Lu Xun did not have the energy to follow the future. However, he would not stop there. "I will at least get nihility" [4] has demarcated the lower limit. It implies that in the near future, $\mathrm{Lu}$ Xun will return as a revolutionary. Because after this sentence, the article again refers to the dirt and the people walking separately, both of which symbolize the ethos and people of the old society that has not been changed. Lu Xun saw them after disappointment, so even if disappointed, he would continue to take actions to wake up them.

In Hope, Lu Xun quoted that "despair is a vain thing, identical with hope" [4]. He noted that he wrote Hope because he was astonished at the depression of the young. He mentions repeatedly that young people are safe, which is not a positive word, but the practice of dwelling in old 
social thoughts and not wanting to wake up. So the safe here can be understood as depression. Lu Xun faced all this with his youth outside of body and self body [4], which were corresponding to the remaining revolutionary forces in society at that time. However, everything was just imagination, for Lu Xun had experienced the same thing once. Therefore, he ended up with emptiness. After the bloody and vigorous revolution, Lu Xun was plunged into spiritual confusion and dismay due to his unsatisfactory results. Finally, even the "youth outside the body" withered away, and everything that might have brought beauty disappeared, as if wiping out Lu Xun's hope completely. But Lu Xun's warrior spirit was still alive: he had not given up his body. Before him, however, it seemed that even the object of his antagonism as well as the night, had vanished. The implication is that despair is as void as hope, which is, "despair is vain, identical with hope". It is not that all the bad things have disappeared, and it is not that the good things will come soon, but from Lu Xun's point of view, everything seems to be meaningless, reduced to a false. Here, Lu Xun has made a clear statement about his nihilistic state of mind.

\section{LU XUN'S STRUGGLE TO "NIHILITY"}

\subsection{Contradiction of Lu Xun}

To sum up, at the time of reform, $\mathrm{Lu}$ Xun was a revolutionary fighter who could not be defeated. Even if there is a setback, he would choose to face it positively. But during the creation of Wild Grass, he had already been hit beyond imagination and found it difficult to change the old society. Lu Xun's spirit of laughing and singing is immortal, but the dim social environment and the people who do not want to wake up leave him to seek in the suffering [6]. Therefore, Lu Xun's nihility is the result of the unity of his realistic experience of suffering and his insistence on hope in his heart. It is a neutralization product. Therefore, after perceiving nihility, how did Lu Xun struggle with it?

Laughing and singing was Lu Xun's attitude in the preface of Chinese version. This is Lu Xun's consistent attitude, but it could not be simply concluded that Lu Xun was still optimistic at that time. He also said that he couldn't laugh or sing because the world was so quiet. This alludes to the harsh social environment and implies that Lu Xun still had an ambition to change the old society. Therefore, he did not give up the pursuit of the ideal because of the perception of nihility. $\mathrm{Lu}$ Xun was ambivalent. He fell into emptiness, but still acted against the unpleasant reality. In Revenge, for example, he did not let the bystanders do what they wanted but took direct revenge. But there existed another paradox: Instead of taking the traditional, violent form of revenge, he killed the bystanders by boring them [2].

\subsection{Lu Xun's Call for the Meaning of Life}

Therefore, Lu Xun, after perceiving nihility, did not hold the idea that everything was meaningless like a nihilist. On the contrary, nihility is only his subjective feeling, what cannot be changed is his pursuit of revolutionary ideals. Wild Grass is a concentrated reflection of his thinking on the meaning of life. People in the old society did not want to wake up and lost the perception of everything, is the real nihility. Beneath this nihility, their lives would lose luster until they rot [3]. Lu Xun took Wild Grass as a comparison, willing to pay anything to arouse people's pursuit of the meaning of life [8].

Then, what is the meaning of life that $\mathrm{Lu}$ Xun calls for? "I have great joy in this death, because I know it has lived" [4]. So he thinks that the meaning of life lies not in the result but in the process. To die in the end is not terrible, never really alive is terrible. It can also be seen from Revenge that $\mathrm{Lu}$ Xun denounced those spectators who were incompetent in the society at that time and doomed to waste their lives because their thoughts were imprisoned by the feudal society [9]. Their lives would eventually be corrupted by their own indifference and nihilism. Lu Xun advocated that the meaning of life does not come from the outside, but from people's perception of their own life and pay the corresponding action to achieve [1]. Undoubtedly, the advocacy here is somewhat close to the existentialism theory in western philosophy, and existentialism does cause some problems to some extent. However, due to the particularity of $\mathrm{Lu}$ Xun himself, this paper does not make a deeper discussion, but focus on his advocacy itself.

To sum up, after realizing the existence of nihility, $\mathrm{Lu}$ Xun did not choose to degenerate or do nothing. Conversely, although he fell into pessimism in suffering, he still struggled on the road of awakening Chinese people. What he resented was the numbness with which people's lives had been corrupted, the wake-up call that pulled them into modern thinking. For Lu Xun himself, whether there was still hope ahead, whether his actions would succeed was no longer the most important thing. There were still a large number of people in the society who had not been awakened. Lu Xun, as a fighter, had not realized his revolutionary ideal, which means that he would continue to struggle for the realization of the revolution.

\section{CONCLUSION}

For Lu Xun, what is more terrible than his own perception of nihility is the nihilism of the Chinese people at that time. Therefore, although $\mathrm{Lu}$ Xun felt the darkness and emptiness, he still would not sink into his own suffering and confusion. Suffering is the background of Lu Xun's life, he would take his own suffering and ahead to more difficult places. Lu Xun's revolutionary ideal is 
the most difficult thing which is to wake up the people to modernization. The paradox is that what makes him feel empty is also the unsatisfying nature of the revolutionary cause. Just as Lu Xun's nothingness is the result of the unity of his experience of suffering and his insistence on hope, his mental state is the result of the unity of his insistence on revolution and his inner nothingness. Hope or despair, for Lu Xun, is no longer a pure or simple thing. The experience of suffering gave Lu Xun a pessimistic background, he found that the pursuit of hope was not allowed, which made him feel empty in his heart. Therefore, in the writing period of Wild Grass, Lu Xun gave up the pursuit of the future and hope, and concentrated on the pursuit of the revolutionary cause and the denunciation of the unsatisfactory status. He no longer believed in hope, but he never stopped to chase his revolutionary ideal, which determines Lu Xun's unique place.

This research focuses on the analysis of the text of Wild Grass and Lu Xun's personal discussion, adhering to the idea that Lu Xun should be studied as Lu Xun itself, rather than applying the template of other theoretical systems. However, to some extent, theoretical supplement is necessary. Future studies will delve into the theoretical concepts in Lu Xun's works and specific analyses from a more professional perspective are needed.

\section{ACKNOWLEDGMENTS}

It is not long since I have been exposed to literature, it is my honor to carry out a research on Lu Xun and his thoughts, whom I respect most. I want to express my gratitude to professor Wang, teaching assistant $\mathrm{Su}$, and classmates who have studied Chinese modern and contemporary literature with me in the past two months. Their guidance and company enabled me to successfully complete this study. In addition, I would like to thank my parents, without your support, I would not have the opportunity to get involved in the field that I have been dreaming of for a long time.

\section{REFERENCES}

[1] J. Cheng Eileen (2017), Literary Remains:Death, Trauma, and Lu Xun's Refusal to Mourn.University of Hawaii Press.

[2] J. X. Guo (2018). On Lu Xun's Thoughts of revenge in Revenge. Northern Literature(14), pp. 16-17.

[3] H. X. Jiang (2019). On the Revenge consciousness in $\mathrm{Lu}$ Xun's wild Grass. Journal of Ankang University(04), pp.37-50.

[4] X. Lu (1976). Wild Grass. Foreign Language Press.

[5] X. Y. Peng (2019). Revenge: A confrontation, two nihility-Wild Grass intensive(reading five). Appreciation of famous Works (34), pp.85-87.
[6] X. Y. Peng (2019). The Mendicant: Nothingness, between "me" and the world - Wild Grass intensive(reading three). Appreciation of famous Works(28), pp.90-93.

[7] B. Wang (2017). A Spiritual Phenomenological Interpretation of "Nihility" in Wild Grass by Lu Xun. Journal of Hangzhou Normal University (Social Science Edition)(02), pp.96-102.

[8] H. Yan (2018). "Article gains and Losses are not in Heaven" : From the nothingness of Existence to the existence of vanity-an interpretation of Lu Xun's way of living. Contemporary literary world (02), pp.97-102.

[9] Q. Zhang (2016). Pity, curse and Nothingness-A Brief Analysis of Lu Xun's Spirit of Enlightenment in Revenge (Ii). Young writer, pp.12-13. 